\title{
Call for cash to end the decay of Berlin's great collections
}

\section{Quirin Schiermeier, Munich}

East Berlin's new government district, with its lavishly renovated ministry buildings, still carries a gaping wound from the Second World War - Humboldt University's crumbling Museum of Natural History. Now, a panel of senior scientists has declared that its 100-million-euro (US\$98-million) renovation is a "national obligation" for Germany.

The wooden windows of the nineteenth-century building - which was bombed by the Allies in 1945 - rattle in the wind, and the plaster on walls and ceilings is falling away, exposing ancient copper water pipes and wiring.

But structural decay is just part of the problem facing what remains one of the world's great natural history museums. So says the report of the panel appointed last year by Humboldt University and the state government of Berlin to advise on how the museum can be revived.

The museum holds over 25 million items, some collected by famous German explorers such as Alexander von Humboldt and the botanist Adelbert von Chamisso. But the collections are threatened by damp, heat and pests, and have not yet been electronically catalogued.

The huge palaeontological, mineralogical and zoological collections are maintained by a staff of 160 and an annual budget of 9 million euros - about a tenth of that of similar museums in London and Paris.

The panel, chaired by Gerhard Neuweiler, a zoologist at the University of Munich and former president of the Wissenschaftsrat, Germany's science council, also suggests a new organization for the museum. Instead of operating its three main departments autonomously, the museum should have a directorgeneral, responsible for integrating its research, exhibits and fund-raising.

But it is unclear where the $\mathbf{1 0 0}$ million euros will come from. The state of Berlin is short of cash and the university's plans to raise funds by selling property have fallen through.

"For the time being, we can hardly expect more than good will," says Neuweiler. At some time in the future he hopes the museum will be saved by money from the federal government.

"The collections belong to our cultural heritage," Neuweiler says. "We owe it to the public and to the international scientific community to conserve them."

\section{Gene-bank expansion plan launched at Earth summit}

\section{Michael Cherry, Johannesburg}

Steps to secure the world's crop diversity and to boost mathematics in Africa are among the initiatives that have emerged from the World Summit on Sustainable Development.

The Johannesburg conference, which ends this week, may have proved difficult for politicians, who were criticized for poor progress on environmental, economic and health issues. But it was useful for the scientists involved in parallel meetings, who discussed food issues and how to build research capacity in developing countries.

One significant move was the launch of an independent Global Conservation Trust. Sanctioned by the UN Food and Agriculture Organization, the trust aims to raise US\$260 million to expand the world's gene banks collections of seeds and other organic material held to protect crop diversity. The launch followed the release of a report revealing that lack of funds prevents many gene banks from planting samples and harvesting material. "If these collections are allowed to fail, we will lose the valuable crop diversity they contain for ever," says coauthor Jeff Waage, an agricultural researcher at Imperial College's Wye campus, UK.

Another initiative, the African Institute when David King, the British government's chief scientific adviser, pledged support. The institute, to be based in the seaside town of Muizenberg near Cape Town, will offer master's degrees in mathematics to students from the whole of Africa. It will be a joint venture by the University of Cambridge, which will supply some of the lecturers, and the South African universities of Cape Town, Stellenbosch and the Western Cape.

Other debates focused on the potential role of genetically modified (GM) crops in for Mathematical Sciences, received a boost

addressing problems of securing food for the developing world. This included a day-long session organized by AfricaBio, a Johannesburg-based association that promotes biotechnology on the continent.

Supporters of the technology pointed out that GM crops are already used in developing countries. According to Nathalie Moll of the Brussels-based lobby group EuropaBio, 5.5 million farmers grew GM crops last year, more than three-quarters of them smallscale farmers, mostly in China. Others cited health benefits. Mycotoxins, poisonous byproducts of the metabolic activity of certain maize fungi, can cause oesophageal cancer, a major killer of black South Africans. These toxins can be reduced by up to $90 \%$ in maize engineered to resist an insect called the maize borer, which makes holes in the plant in which fungi grow, botanist Klaus Ammann of the University of Berne in Germany told the meeting.

Many African countries remain opposed to transgenic crops. Zimbabwe and Zambia for example, recently outlawed their use and have refused to accept GM maize as food aid (see Nature 418, 571-572; 2002). "Biotechnology must not be imposed on Africa, but developed from within it," says Jane Morris of the African Centre for Gene Technologies at the South African Council for Scientific and Industrial Research (CSIR) in Pretoria.

Other delegates pointed out that many countries lack a culture of independent regulatory agencies - a point unintentionally highlighted by Ben Ngubane, South Africa's science minister. He castigated Lungile Shoba, a molecular biologist at the CSIR, for pointing out that the panel set up to discuss transgenic crops contained no opponents of the technology. "Remember I am your minister," he said, wagging his finger at her.

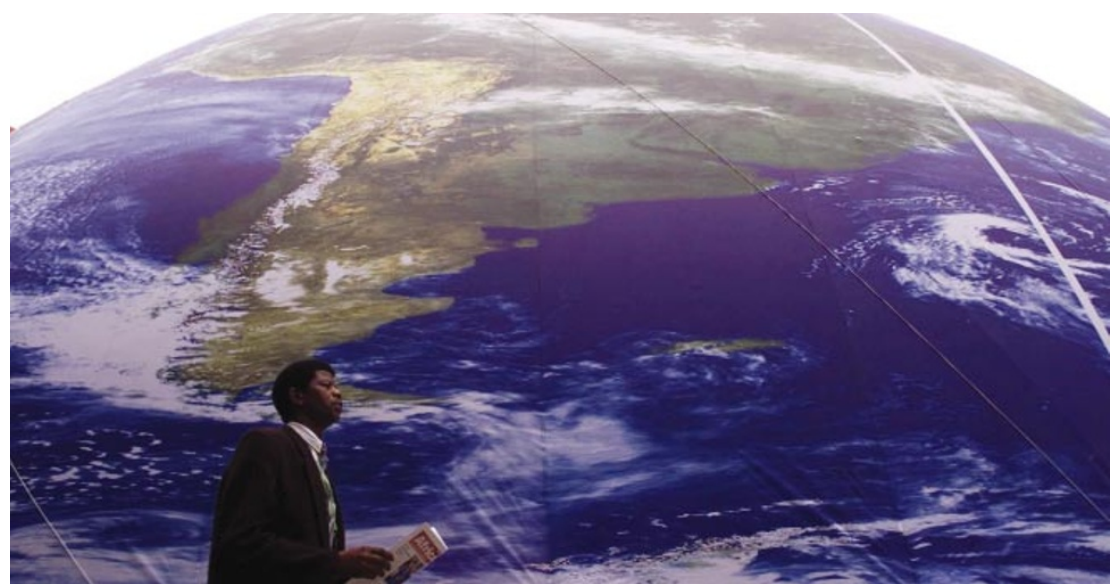

One world: and many questions for delegates passing by the giant globe in Johannesburg last week. 